\title{
(6. \\ Density, diversity and community composition of trees in tropical thorn forest, peninsular India
}

ISSN: $2220-4822$

\author{
J. Evitex-Izayas, M. Udayakumar* \\ Department of Plant Science, Manonmaniam Sundaranar University, Abishekapatti, Tirunelveli - 627012, Tamil Nadu, \\ India
}

\begin{abstract}
Tropical thorn forests (TTFs) are characterized by the presence of small and thorny trees which usually shed their leaves in the dry season. A quantitative phytosociological study was conducted in Uthumalai Reserve Forest of Peninsular India to record density, species richness, diversity and population structure of trees. The diameter of all free standing trees $\geq 1 \mathrm{~cm}$ diameter at breast height $(\mathrm{DBH}, \mathrm{cm})$ was measured at $1.37 \mathrm{~m}$ above the ground. A sum of 4135 trees $\geq 1 \mathrm{~cm} \mathrm{DBH}$ was recorded from one hectare study plot. With 2272 (54.94\%) individuals Dalbergia spinosa dominated the study plot followed by Commiphora berryi (484, 11.70\%), Grewia flavescens (259, 6.26\%), Dichrostachys cinerea (206, 4.98\%) and Anogeissus pendula $(171,4.14 \%)$. In total, 26 species belonged to 19 genera and 15 families found in one ha study plot. The family Mimosaceae had a large number of species followed by Apocynaceae, Capparidaceae, Tiliaceae, Rhamnaceae and Rubiaceae (each 2 species). Stand basal area of tree community recorded as $15.238 \mathrm{~m}^{2} \mathrm{ha}^{-1}$. Commiphora berryi constituted $50.80 \%\left(7.74 \mathrm{~m}^{2} \mathrm{ha}^{-1}\right)$ of stand basal area followed by Dalbergia spinosa $\left(19.43 \%, 2.96 \mathrm{~m}^{2} \mathrm{ha}^{-1}\right)$. The forest showed a reverse J shaped population structure. Shannon diversity $(H)$, equitability $\left(H^{\prime}\right)$ and Simpson's dominance $(D)$ indices of the study area were recorded as 1.76, 0.54 and 0.335, respectively. Dalbergia spinosa, Commiphora berryi, Grewia flavescens, Dichrostachys cinerea and Anogeissus pendula topped the species important value index with scores 87.80 , $73.53,20,19.79,17.43$ scores, respectively. In the family important value index, Papilionaceae topped the list followed by Burseraceae and Mimosaceae with scores 129.32, 74.23 and 34.43, respectively. The study area is endowed with moderate species richness and diversity and acts as one of the homes for an IUCN's vulnerable tree species.
\end{abstract}

M. Udayakumar

Email: udayakumar@msuniv.

ac.in

KEYWORDS: Population structure, Tamil Nadu, Tree diversity, Tropical forest, Species-area curve

\section{INTRODUCTION}

Tropical forests cover just $10 \%$ of the earth's surface but contain one half of all the existing plant species (Mayaux et al., 2005). In addition, tropical forests have been recognized as a home for a significant proportion of total global biodiversity. These forests are the richest biological communities and it provides vital ecosystem services such as carbon storage and sequestration, prevention of soil erosion, and species conservation (Myers et al., 2000). Among types of tropical forests, dry forests occupy 8 to $13 \%$ geographical cover globally (Hansen et al., 2013). South Asia, South America and sub-Saharan Africa (including Madagascar) together have the largest geographical cover under tropical dry forests (FAO, 2000). In addition, the Caribbean, Central America, South East Asia, Northern Australia also has a significant proportion of land areas under Tropical Dry Forests (TDFs).
TDFs experience 250-2000 mm annual rainfall and 3-4 months of the drought period. In the dry regions, plants have low water availability and adapted for their survival in the dry season (Murphy and Lugo, 1986). TDFs have low canopy and high tree diversity (Kumar et al., 2010). A large proportion of TDFs cleared for the expansion of agriculture in India and the Americas (Kowero, 2003; Gillespie et al., 2012). For instance, two thirds of Americas TDFs converted for other uses (Portillo-Quintero and Sánchez Azofeifa, 2010). According to Miles et al., (2006), only less than half of the world's dry forests are legally protected. Besides, just $<10 \%$ of the undisturbed dry forests remain exists in pacific islands (Gillespie et al., 2012). Compared to humid forest, research on TDFs is limited. Though, TDFs support the livelihood and economic wellbeing of the ignificant human population, financial funding for research has been limited (Miles et al., 2006; Shepherd et al., 2002). However, TDFs are home to rich biodiversity thus protection of this forest is essential from further loss. Notably, research on Indian TDF particularly, Tropical Thorn Forest (TTF)

Copyright: (C) The authors. This article is open access and licensed under the terms of the Creative Commons Attribution License (http://creativecommons.org/licenses/by/4.0/) which permits unrestricted, use, distribution and reproduction in any medium, or format for any purpose, even commercially provided the work is properly cited. Attribution — You must give appropriate credit, provide a link to the license, and indicate if changes were made. 
has been very limited. Thus, the present study aimed to record density, species richness and diversity of woody plants in a TTF ecosystem located at Uthumalai, Tirunelveli, Peninsular India.

\section{METHODS}

\section{Study Area}

The study area, the Uthumalai region legally protected as a Reserve Forest by the Department of Forest, Government of Tamil Nadu since 1948. Thus, collection of fuelwood, illegal poaching and cutting of trees are banned. The study area is located at Tirunelveli district, Tamil Nadu. Geographical coordinates of the study area are 8059'51.0" North latitude and 77035'26.8" Eastern longitude (Figure 1). The forest type of study area has been recognized as Tropical Thorn Forest (TTF), (Champion and Seth, 1968). The TTF is characterized by the presence of small and thorny trees which usually shed their leaves in the dry season. Fleshy, succulent plants, dryland-adapted grasses and thorny bushes form the ground layer. A considerable number of annual plants germinate, grow, develop, reproduce and die during the short rainy season. The study area receives a low annual rainfall $(680 \mathrm{~mm})$ and experiences a high mean minimum and maximum temperatures (range $25-41^{\circ} \mathrm{C}$ ). This region receives a major proportion of the annual rainfall during the northeast monsoon (October-December) and experiences dry periods during April-September. Soil is red laterite-red loamy in nature. The forest acts as a home for a large number of Acacias. Water availability acts as a primary limiting factor for plants in dry environments. Acacia planifrons, A. horrida, A. mellifera, Chloroxylon swietenia, Commiphora berryi, Dalbergia spinosa and Dichrostachys cinerea are characteristic species of TTF.

\section{Field Method}

A sum of one hundred $10 \mathrm{~m} \times 10 \mathrm{~m}$ square plots (total area 1 ha) laid randomly across URF to record density, frequency, species richness and diversity of trees. Diameter of all free standing trees $\geq 1 \mathrm{~cm}$ diameter at breast height (DBH, cm) was measured at $1.37 \mathrm{~m}$ above the ground as per Center for Tropical Forest Science, Panama guidelines (Condit, 1998). DBH measured and recorded in the field data book. All recorded species were identified using regional floras (Gamble and Fischer, 1915-35; Manickam et al., 2008) and family nomenclature followed Bentham and Hooker classification. Botanical name and author citation followed The Plant List (http://www.theplantlist.org/).

Basal area of trees calculated using the formula $\mathrm{BA}=\pi \times$ $(\mathrm{DBH} / 2)^{2}$, where BA is a basal area $\left(\mathrm{cm}^{2}\right) ; \pi$ is constant and $\mathrm{DBH}$ is the diameter at breast height $(\mathrm{cm})$. Dominant and important species and families of the study area were identified using species (IVI) and family important value indices (FIV) (as in Misra, 1968; Mori et al., 1983). Species-area curve was constructed by plotting area $(0.1,0.2,0.3 \ldots .1 \mathrm{ha})$ on $x$ axis and the cumulative number of recorded species on the $y$ axis (McIntosh, 1985).

\section{Population Structure}

All recorded trees were divided into ten classes according to their diameter (cm): 1) 1-2 cm dbh; 2) 2.1-3 cm; 3) 3.1-4 cm; 4) 4.1$5 \mathrm{~cm}$; 5) $5.1-6 \mathrm{~cm}$; 6) $6.1-7 \mathrm{~cm}$; 7) $7.1-8 \mathrm{~cm}$; 8) $8.1-9 \mathrm{~cm}$; 9) 9.1$10 \mathrm{~cm}$; and 10) $\geq 10 \mathrm{~cm}$ dbh. The total number of trees in each of the ten diameter classes and their contribution to the forest stand basal area was calculated and population structure enumerated.

\section{Diversity Indices}

Species diversity, equitability and dominance indices were calculated for all the study plots together (one ha) by Shannon's diversity $(H)$, Shannon's evenness (EH) and Simpson's dominance $(D)$, respectively (as in Magurran, 1988). These are information statistics used to define the diversity of a community. Where: $H=$ the Shannon diversity index; $P_{i}=$ fraction of the entire population made up of species $i$;

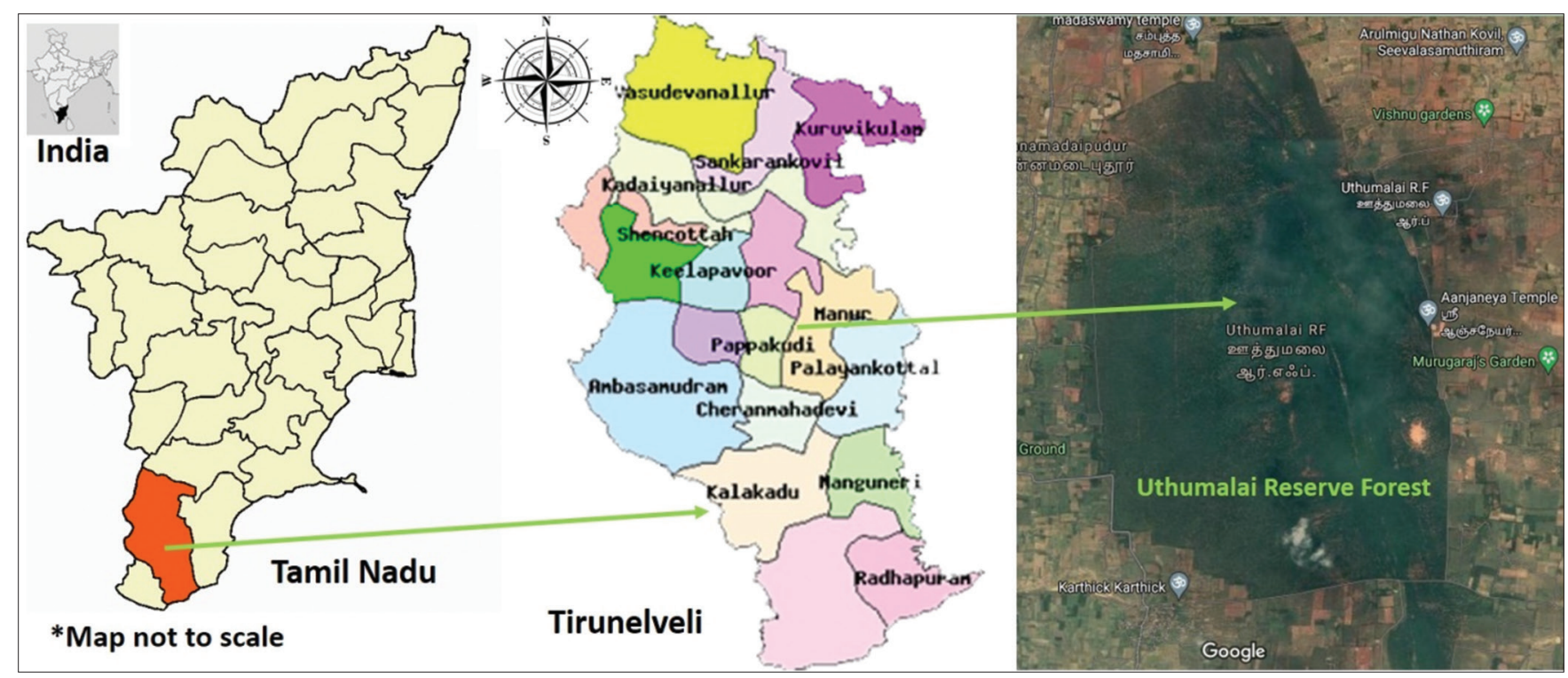

Figure 1: Map of Uthumalai Reserve Forest, Tirunelveli wherein quantitative ecological study conducted 
$S=$ number of species encountered; $\Sigma=$ sum from species 1 to species $S$. The Shannon diversity index $(H)$ is commonly used to characterize species diversity in a community. This index considers both the abundance and evenness of the species present. Shannon's equitability $\left(E_{H}\right)$ calculated by dividing $H$ by $H_{\max }\left(\right.$ where $\left.H_{\max }=\ln S\right)$. Shannon's evenness $\left(E_{H}\right)=H / H_{\max }=$ $\mathrm{H} / \mathrm{ln} S$. Simpson's Dominance $(D)=\sum \mathrm{n}_{\mathrm{i}}\left(\mathrm{n}_{\mathrm{i}} \mathrm{-l}\right) / \mathrm{N}(\mathrm{N}-1)$. Where: $\mathrm{D}$ is a measure of dominance; $p$ represents the proportional abundance of the $i$ th species in the community.

\section{RESULTS}

\section{Density}

As the whole, 4135 trees $\geq 1 \mathrm{~cm}$ DBH recorded from one hectare study plot. The mean density of trees in a sub-plot $\left(100 \mathrm{~m}^{2}\right)$ was $159.03 \pm 11.21$ (Standard Deviation, s.d.) trees. The contribution of species' to total stand density varied significantly. With 2272 (54.94\%) individuals, Dalbergia spinosa dominated the study area followed by Commiphora berryi (484 individuals, $11.70 \%)$, Grewia flavescens (259, 6.26\%), Dichrostachys cinerea (206, 4.98\%) and Anogeissus pendula (171, 4.14\%), while ten species including Albizia amara, A. mellifera, A. leucophloea and Grewia villosa cumulatively represented by 20 individuals $(<1 \%)$. Five species namely, Dalbergia spinosa, Commiphora berryi, Grewia flavescens, Dichrostachys cinerea and Anogeissus pendula constituted $82.03 \%$ of the tree community in the study area. Species represented by a large number of individuals also occurred frequently within the study plot, (Table 1).

\section{Species Richness}

In total, 26 species belonged to 19 genera and 15 families found in one ha study plot. The family Mimosaceae had a large number of species followed by Apocynaceae, Capparidaceae, Tiliaceae, Rhamnaceae. Rubiaceae (each 2 species), whereas nine families including Boraginaceae, Burseraceae, Combretaceae and Erythroxylaceae had single species' each in the study area. The number of trees represented by families varied considerably. The family Papilionaceae had a large number of individuals (2272 trees) followed by Burseraceae (434) and Mimosaceae (434), while Euphorbiaceae, Sapindaceae and Verbenaceae had just two individuals each in the study area.

\section{Species Area Curve}

The species-area curve nearly levelled-off at 0.8 ha as no species has been added after 0.8 hectare study area. The species-area curve reached an asymptote at $0.8 \mathrm{ha}$. The rate of rising of species-area curve was 1.78 . Tree inventory beyond 1-ha area was not added even a single species up to $1.25 \mathrm{ha}$. We captured nearly $50 \%$ of species in just 0.3 ha area (Figure 2).

\section{Basal Area}

Stand basal area of tree community recorded as $15.238 \mathrm{~m}^{2} \mathrm{ha}^{-1}$. The contribution of each species' to forest stand basal area varied notably. Commiphora berryi constituted 50.80\% (7.74 $\left.\mathrm{m}^{2} \mathrm{ha}^{-1}\right)$
Table 1: Botanical name, family, density and frequency of plants recorded from TTF, Uthumalai, Tamil Nadu

\begin{tabular}{|c|c|c|c|c|}
\hline \multicolumn{2}{|c|}{ No. Botanical name } & \multirow{2}{*}{$\begin{array}{l}\text { Family } \\
\text { Papilionaceae }\end{array}$} & \multicolumn{2}{|c|}{ Density Frequency } \\
\hline 1 & Dalbergia spinosa Roxb. & & 2272 & 100 \\
\hline 2 & Commiphora berryi (Arn.) Engl. & Burseraceae & 484 & 82 \\
\hline 3 & Grewia flavescens Juss. & Tiliaceae & 259 & 73 \\
\hline 4 & $\begin{array}{l}\text { Dichrostachys cinerea (L.) Wight } \\
\text { \& Arn. }\end{array}$ & Mimosaceae & 206 & 62 \\
\hline 5 & Anogeissus pendula Edgew. & Combretaceae & 171 & 60 \\
\hline 6 & Erythroxylum monogynum Roxb. & Erythroxylaceae & 161 & 66 \\
\hline 7 & Acacia horrida (L.) Willd. & Mimosaceae & 127 & 57 \\
\hline 8 & $\begin{array}{l}\text { Catunaregam spinosa (Thunb.) } \\
\text { Tirveng. }\end{array}$ & Rubiaceae & 90 & 42 \\
\hline 9 & $\begin{array}{l}\text { Canthium coromandelicum } \\
\text { (Burm. f.) Alston }\end{array}$ & Rubiaceae & 67 & 33 \\
\hline 10 & Ehretia laevis Roxb. & Boraginaceae & 57 & 28 \\
\hline 11 & Acacia planifrons Wight \& Arn. & Mimosaceae & 50 & 26 \\
\hline 12 & Ziziphus xylopyrus (Retz.) Willd. & Rhamnaceae & 48 & 23 \\
\hline 13 & Prosopis cineraria (L.) Druce & Mimosaceae & 45 & 23 \\
\hline 14 & Chloroxylon swietenia DC. & Rutaceae & 45 & 30 \\
\hline 15 & Carissa spinarum L. & Apocynaceae & 16 & 10 \\
\hline 16 & Crateva religiosa G. Forst. & Capparidaceae & 14 & 10 \\
\hline 17 & Grewia villosa Willd. & Tiliaceae & 6 & 4 \\
\hline 18 & Albizia amara (Roxb.) B.Boivin & Momosaceae & 4 & 4 \\
\hline 19 & Carissa carandas L. & Apocynaceae & 3 & 2 \\
\hline 20 & Euphorbia antiquorum L. & Euphorbiaceae & 2 & 2 \\
\hline 21 & Dodonaea viscosa (L.) Jacq. & Sapindaceae & 2 & 2 \\
\hline 22 & Gmelina asiatica L. & Verbenaceae & 2 & 2 \\
\hline 23 & Acacia mellifera (M. Vahl) Benth. & Mimosaceae & 1 & 1 \\
\hline 24 & Acacia leucophloea (Roxb.) Willd. & Mimosaceae & 1 & 1 \\
\hline 25 & $\begin{array}{l}\text { Ziziphus nummularia (Burm.f.) } \\
\text { Wight \& Arn. }\end{array}$ & Rhamnaceae & 1 & 1 \\
\hline 26 & Cadaba trifoliata Wight \& Arn. & Capparidaceae & 1 & 1 \\
\hline & Total & 15 & 4135 & 745 \\
\hline
\end{tabular}

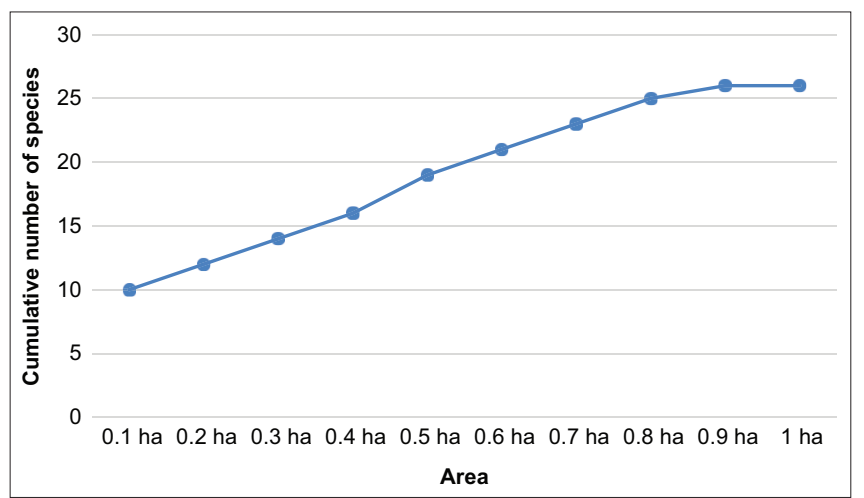

Figure 2: Species-area curve recorded for one ha plot in Uthumalai, Tirunelveli

of stand basal area followed by Dalbergia spinosa (19.43\%, $2.96 \mathrm{~m}^{2} \mathrm{ha}^{-1}$ ). All other species together contributed $29.77 \% \mathrm{BA}$ in the study area. Likewise, the contribution of each family to the forest stand basal area also differed significantly. The family Burseraceae alone contributed more than a half of BA $(50.8 \%$, $\left.7.74 \mathrm{~m}^{2} \mathrm{ha}^{-1}\right)$ followed by Papilionaceae $\left(19.43 \%, 2.96 \mathrm{~m}^{2} \mathrm{ha}^{-1}\right)$, Mimosaceae $\left(13.43 \%, 2.05 \mathrm{~m}^{2} \mathrm{ha}^{-1}\right)$ and Combretaceae $(5.28 \%$, $0.81 \mathrm{~m}^{2} \mathrm{ha}^{-1}$ ), whereas the rest of the species ( 11 species together) added just $11.06 \%$ BA in the study area (Figure 3).

Contribution of tree diameter classes varied considerably. The largest diameter class $\geq 10 \mathrm{~cm}$ DBH had the maximum BA 


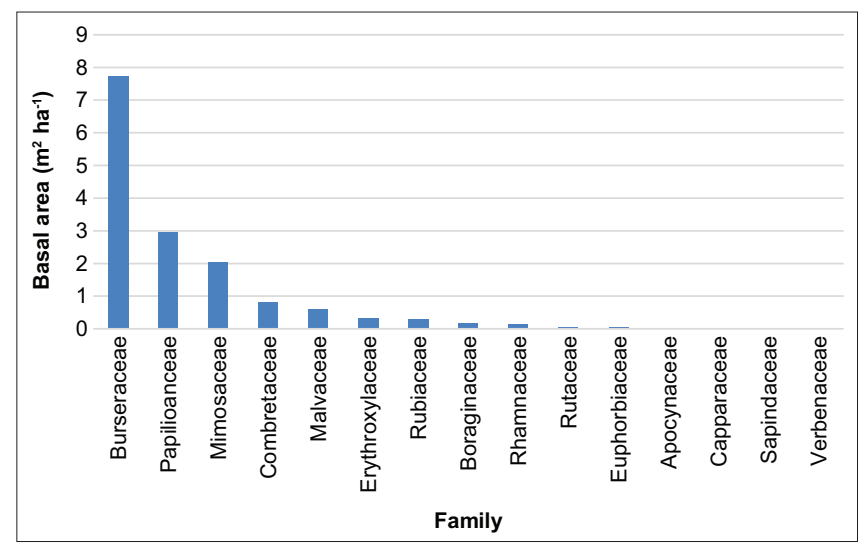

Figure 3: Basal area of families recorded from study area

$\left(7.6 \mathrm{~m}^{2} \mathrm{ha}^{-1}\right)$ followed by $1.0-2 \mathrm{~cm}\left(2.03 \mathrm{~m}^{2} \mathrm{ha}^{-1}\right)$ and $3.1-4 \mathrm{~cm}$ $\left(1.108 \mathrm{~m}^{2} \mathrm{ha}^{-1}\right)$, whereas the diameter class $9.1-10 \mathrm{~cm}$ had the least BA $\left(0.226 \mathrm{~m}^{2} \mathrm{ha}^{-1}\right)$ in the study area (Figure 4). The proportion of forest stand density formed by diameter classes varied widely. The lowest diameter class $(\geq 1-3 \mathrm{~cm}$ DBH) constituted $52.4 \%$ of the tree community while large diameter classes viz., $\geq 9.1-11,11.1-12 \ldots \geq 21 \mathrm{~cm}$ cumulatively formed just $8.5 \%$ tree community in TTF.

\section{Population Structure}

The population structure based on diameter class frequency is an expanding one and showed a reverse J shaped pattern (Figure 5). The study plot had greater number of smaller trees (low-diameter classes). This pattern indicates that the present study sites support a growing healthy population. A reverse J pattern of forest structure signifies a healthy recruitment of trees in forest sites.

\section{Diversity Indices}

Shannon diversity index $(H)$ of study area recorded as 1.76 , while Shannon Equitability index $\left(H^{\prime}\right)$ was 0.54 . Shannon dominance index $(D)$ calculated as 0.335 for one ha study plot. Study area endowed with moderate species richness and diversity hence scored a mediocre value.

\section{Species and family important value indices}

Important value index considered relative density, frequency and dominance of species. Dalbergia spinosa, Commiphora berryi, Grewia flavescens, Dichrostachys cinerea and Anogeissus pendula topped the list with 87.80, 73.53, 20, 19.79, 17.43 scores, respectively, while Acacia leucophloea, Ziziphus nummularia and Cadaba fruticosa secured last three positions, (Table 2).

Likewise, FIV considered relative density, diversity and dominance of families. In family important value index, Papilionaceae topped the list followed by Burseraceae and Mimosaceae with scores 129.32, 74.23 and 34.43, respectively. While, four families, Capparidaceae, Euphorbiaceae, Sapindaceae and Verbenaceae jointly secured the score $<1$ in study area, (Table 3).

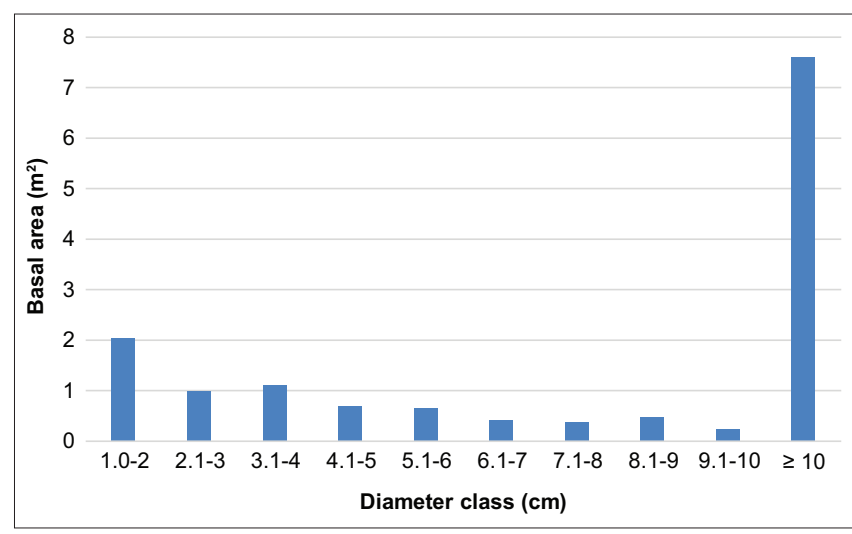

Figure 4: Basal area of various diameter classes of trees in study area

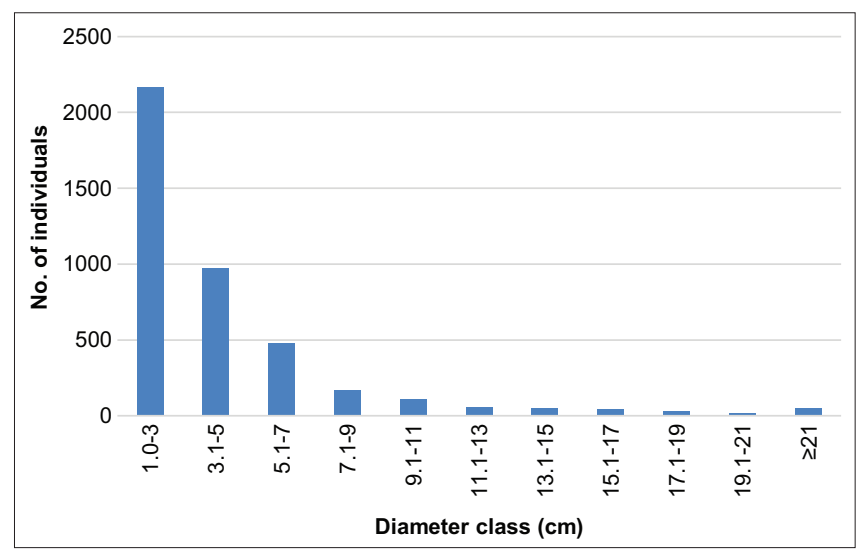

Figure 5: Population structure of trees in study area

\section{DISCUSSIONS}

\section{Forest Tree Stand Density}

The study plot had large number of trees i.e. 4135 stems ha $^{-1}$ $(\geq 1 \mathrm{~cm} \mathrm{DBH})$. In general, forest dynamics plots (FDP) established as per CTFS guidelines record all free standing trees with size $\geq 1 \mathrm{~cm}$ DBH. In a 50 ha FDP located in Mudumalai, Tamil Nadu Sukumar et al., (1992) recorded 25,929 (mean 518.58 trees $\mathrm{ha}^{-1}$, size $\geq 1 \mathrm{~cm}$ DBH) trees. One of the world's oldest FDP located in Barro Colorado Island, Panama had a minimum of 2795.83 trees $\mathrm{ha}^{-1}$ to a maximum of 5097.46 trees ha-1 $^{-1}$ (mean trees ha ${ }^{-1}, 4880.28$ ), (Hubbell and Foster, 1983, 1992; Condit, 1998). Tree density found in study area is higher than in Mudumalai's FDP while lower than that of Panama's FDP.

Tree diversity studies usually record trees $\geq 10 \mathrm{~cm} \mathrm{DBH}$. There are 310 trees with size $\geq 10 \mathrm{~cm}$ DBH in study plots. On one hand, tree density ( 310 trees in $\geq 10 \mathrm{~cm} \mathrm{DBH)} \mathrm{of} \mathrm{TTF} \mathrm{is} \mathrm{higher}$ than in semi-evergreen, moist deciduous, dry deciduous and scrub/savannah forests of Western Ghats (302, 276, 243 and 191 trees ha $^{-1}$, respectively; Utkarsh et al., 1998); semi-evergreen and thorn scrub forests of Western Ghats (232, 156 trees ha' Joseph et al., 2008); and, tropical dry forests of Chattishgarh (216-292 trees ha ${ }^{-1}$; Bajalwan, 2010). 
Table 2: Important value index recorded for species from TTF, Uthumalai, Tamil Nadu. (RD, relative density; Rfre, relative frequency; RDom, relative dominance)

\begin{tabular}{|c|c|c|c|c|c|c|c|c|c|}
\hline No. & Species & Density & Frequency & $\mathrm{BA} \mathrm{m}^{2} \mathrm{ha}^{-1}$ & RD & RFre & RDom & IVI & Rank \\
\hline 1 & Dalbergia spinosa & 2272 & 100 & 2.960 & 54.94 & 13.42 & 19.43 & 87.80 & 1 \\
\hline 2 & Commiphora berryi & 484 & 82 & 7.743 & 11.70 & 11.00 & 50.82 & 73.53 & 2 \\
\hline 3 & Grewia flavescens & 259 & 73 & 0.601 & 6.26 & 9.79 & 3.95 & 20.01 & 3 \\
\hline 4 & Dichrostachys cinerea & 206 & 62 & 0.836 & 4.98 & 8.32 & 5.49 & 18.79 & 4 \\
\hline 5 & Anogeissus pendula & 171 & 60 & 0.805 & 4.13 & 8.05 & 5.29 & 17.47 & 5 \\
\hline 6 & Erythroxylon monogynum & 161 & 66 & 0.327 & 3.89 & 8.86 & 2.15 & 14.90 & 6 \\
\hline 7 & Acacia horrida & 127 & 57 & 0.531 & 3.07 & 7.65 & 3.49 & 14.21 & 7 \\
\hline 8 & Catunaregam spinosa & 90 & 42 & 0.161 & 2.18 & 5.64 & 1.06 & 8.87 & 8 \\
\hline 9 & Canthium coromandelicum & 67 & 33 & 0.146 & 1.62 & 4.43 & 0.96 & 7.01 & 9 \\
\hline 10 & Prosopis cineraria & 45 & 23 & 0.395 & 1.09 & 3.09 & 2.59 & 6.77 & 10 \\
\hline 11 & Ehretia laevis & 57 & 28 & 0.169 & 1.38 & 3.76 & 1.11 & 6.25 & 11 \\
\hline 12 & Chloroxylon swietenia & 45 & 30 & 0.063 & 1.09 & 4.03 & 0.41 & 5.53 & 12 \\
\hline 13 & Acacia planifrons & 50 & 26 & 0.125 & 1.21 & 3.49 & 0.82 & 5.52 & 13 \\
\hline 14 & Ziziphus xylopyrus & 48 & 23 & 0.133 & 1.16 & 3.09 & 0.87 & 5.12 & 14 \\
\hline 15 & Carissa spinarum & 16 & 10 & 0.017 & 0.39 & 1.34 & 0.11 & 1.84 & 15 \\
\hline 16 & Capparis sepiaria & 14 & 10 & 0.011 & 0.34 & 1.34 & 0.07 & 1.75 & 16 \\
\hline 17 & Albizia amara & 4 & 4 & 0.116 & 0.09 & 0.54 & 0.76 & 1.39 & 17 \\
\hline 18 & Grewia villosa & 6 & 4 & 0.011 & 0.14 & 0.54 & 0.07 & 0.75 & 18 \\
\hline 19 & Euphorbia antiquorum & 2 & 2 & 0.036 & 0.05 & 0.27 & 0.23 & 0.55 & 19 \\
\hline 20 & Acacia mellifera & 1 & 1 & 0.038 & 0.02 & 0.13 & 0.25 & 0.41 & 20 \\
\hline 21 & Carissa carandas & 3 & 2 & 0.001 & 0.07 & 0.27 & 0.008 & 0.35 & 21 \\
\hline 22 & Dodonaea viscosa & 2 & 2 & 0.001 & 0.05 & 0.27 & 0.008 & 0.32 & 22 \\
\hline 23 & Gmelina asiatica & 2 & 2 & 0.001 & 0.05 & 0.27 & 0.004 & 0.32 & 23 \\
\hline 24 & Acacia leucophloea & 1 & 1 & 0.006 & 0.02 & 0.13 & 0.038 & 0.20 & 24 \\
\hline 25 & Ziziphus nummularia & 1 & 1 & 0.003 & 0.02 & 0.13 & 0.017 & 0.18 & 25 \\
\hline \multirow[t]{2}{*}{26} & Cadaba fruticosa & 1 & 1 & 0.001 & 0.02 & 0.13 & 0.004 & 0.16 & 26 \\
\hline & Total & 4135 & 745 & 15.238 & 100 & 100 & 100 & 300 & - \\
\hline
\end{tabular}

Table 3: Important value index recorded for families in TTF, Uthumalai, Tamil Nadu. (RD, relative density; RDiv, relative diversity; RDom, relative dominance)

\begin{tabular}{|c|c|c|c|c|c|c|c|c|}
\hline \multicolumn{2}{|c|}{ No. Family } & \multirow{2}{*}{$\frac{\text { Density }}{2272}$} & \multirow{2}{*}{$\begin{array}{c}\begin{array}{c}\text { BA } \\
\left(\mathrm{m}^{2} \mathrm{ha}^{-1}\right)\end{array} \\
2.960\end{array}$} & \multirow{2}{*}{$\begin{array}{c}\text { RD } \\
54.94\end{array}$} & \multirow{2}{*}{$\begin{array}{c}\text { RDiv } \\
54.94\end{array}$} & \multirow{2}{*}{$\begin{array}{l}\text { RDom } \\
19.42\end{array}$} & \multirow{2}{*}{$\begin{array}{c}\text { FIV } \\
129.32\end{array}$} & \multirow{2}{*}{$\frac{\text { Rank }}{1}$} \\
\hline 1 & Papilionaceae & & & & & & & \\
\hline 2 & Burseraceae & 484 & 7.743 & 11.70 & 11.70 & 50.82 & 74.22 & 2 \\
\hline 3 & Mimosaceae & 434 & 2.047 & 10.49 & 10.49 & 13.44 & 34.43 & 3 \\
\hline 4 & Malvaceae & 265 & 0.612 & 6.41 & 6.41 & 4.02 & 16.83 & 4 \\
\hline 5 & Combretaceae & 171 & 0.805 & 4.13 & 4.13 & 5.29 & 13.56 & 5 \\
\hline 6 & Erythroxylaceae & 161 & 0.327 & 3.89 & 3.89 & 2.15 & 9.93 & 6 \\
\hline 7 & Rubiaceae & 157 & 0.307 & 3.79 & 3.80 & 2.01 & 9.61 & 7 \\
\hline 8 & Boraginaceae & 57 & 0.169 & 1.38 & 1.38 & 1.11 & 3.87 & 8 \\
\hline 9 & Rhamnaceae & 49 & 0.136 & 1.18 & 1.18 & 0.89 & 3.26 & 9 \\
\hline 10 & Rutaceae & 45 & 0.063 & 1.09 & 1.09 & 0.41 & 2.59 & 10 \\
\hline 11 & Apocynaceae & 19 & 0.018 & 0.46 & 0.45 & 0.12 & 1.04 & 11 \\
\hline 12 & Capparaceae & 15 & 0.011 & 0.36 & 0.36 & 0.07 & 0.80 & 12 \\
\hline 13 & Euphorbiaceae & 2 & 0.036 & 0.05 & 0.05 & 0.23 & 0.33 & 13 \\
\hline 14 & Sapindaceae & 2 & 0.001 & 0.05 & 0.05 & 0.008 & 0.10 & 14 \\
\hline \multirow[t]{2}{*}{15} & Lamiaceae & 2 & 0.0006 & 0.05 & 0.04 & 0.004 & 0.10 & 15 \\
\hline & Total & 4135 & 15.238 & 100 & 100 & 100 & 300 & - \\
\hline
\end{tabular}

On the other hand, tree density $(\geq 10 \mathrm{~cm}$ DBH) of TTF is lower than in many dry forests within India. Earlier, Kadavul (1999) recorded 367-667 trees ha-1 from the tropical semi-evergreen forest, Tamil Nadu; Jha and Singh (1990) found 559 trees ha-1 $^{-1}$ from tropical dry forests of Vindhyan hills, India; Prasad and Pandey (1992) enlisted 476 trees ha-1 in deciduous forests of Mandla, India; Murali et al., (1996) encountered 905 trees ha $^{-1}$ from dry deciduous forests of BR Hills, India; Sukumar et al., (1997) found 518 trees ha-1 from dry deciduous forests of Mudumalai, India; and, Kumar et al., (2010) recorded 458-728 trees $\mathrm{ha}^{-1}$ from tropical dry deciduous forests of Udaipur, India. TTFs are low-statured forest tends to have a large number of small diameter trees (Champion and Seth, 1968).

TTF acts as one of the homes for IUCNs' vulnerable tree species Chloroxylon swietenia which is represented by 45 individuals $\mathrm{ha}^{-1}$. Earlier, Tiwari and Ravikumar (2018) observed the species from dry forests of Hosur Forest Division in Tamil Nadu. They recorded 27.8, 25.25 and 12.62 trees ha $^{-1}$ from southern tropical dry mixed deciduous, Hardwickia and southern thorn scrub forests, respectively.

\section{Species Richness}

This the study quantified 26 tree species ha-1. The observed species richness ha-1 in TTF is higher than in many forests within India. Tropical dry evergreen forests (TDEF) in Villupuram, Tamil Nadu had 21 species (Ramanujam and Kadamban, 2001); deciduous forests of Mandla endowed with 12-14 (Prasad and Pandey, 1992); tropical dry forests of Chattishgarh, India recorded 5-9 (Bajalwan, 2010); tropical dry forests of Vindhyan hills possessed 4-23 (Sagar et al., 2003); and, tropical dry deciduous forests of Madhya Pradesh, India had 2-14 (Pande, 2005).

Tree species richness of TTF is also higher than in some dry forest types of Tamil Nadu state. Tiwari and Ravikumar (2018) found 17, 20,17, 13 and 14 tree species from Carnatic umbrella thorn, dry bamboo brake, Hardwickia, riverine and southern dry scrub forests, respectively. These forests are located within Hosur Forest Division, Tamil Nadu. 
Conversely, species richness of TTF is lower compared to TDEFs of Nagapattinam and Tiruvarur districts, Tamil Nadu (28-34 species ha-1; Udayakumar, 2013); TDEF of Cuddalore, Tamil Nadu (28-31 species ha-1 ${ }^{-1}$ King, 1997; Parthasarathy and Karthikeyan, 1997; Venkateswaran and Parthsarathy, 2003); TDEFs of Pudukottai, Tamil Nadu (28-35 species ha ${ }^{-1}$; Mani and Parthasarathy, 2005); dry deciduous forests of BR Hills, India (69-72 species ha ${ }^{-1}$; Murali et al., 1996; Sukumar et al., 1997); tropical deciduous forest of Uttar Pradesh (70 species ha-1); a dry deciduous forest of Karnataka (46 species ha ${ }^{-1}$; Krishnamurthy et al., 2010); a tropical dry forest of Rajasthan (50 species ha-1; Kumar et al., 2011); dry deciduous of Andhra Pradesh (31-55 species ha' ${ }^{-1}$; Rao et al., 2011); and, dry deciduous of Mudumalai, Tamil Nadu (64 species ha ${ }^{-1}$; Joseph et al., 2008). Dry forests are endowed with low to moderate tree diversity due to prolonged dry season and low water availability.

\section{Tree Stand Basal Area}

Tree basal area of TTF is higher than in some dry forests. Udayakumar (2013) found 10.78 to $14.3 \mathrm{BA} \mathrm{m}^{2} \mathrm{ha}^{-1}$ for two TDEF sites in Tiruvarur, Tamil Nadu; Ramanujam and Kadamban (2001) recorded $4.31 \mathrm{~m}^{2} \mathrm{ha}^{-1}$ for the same kind of forest from Villupuram, Tamil Nadu; Shankar et al., (1998) estimated $7.9 \mathrm{~m}^{2} \mathrm{ha}^{-1}$ for the deciduous scrub forest, BR hills, India; Bajalwan (2010) quantified 4.99-7.34 $\mathrm{m}^{2} \mathrm{ha}^{-1}$ from tropical dry forest of Chattishgarh, India; Sagar et al., (2003) found 1.30-13.78 $\mathrm{m}^{2} \mathrm{ha}^{-1}$ for tropical dry forest of Vindhyan hills, India; Reddy and Ugle (2008) enumerated $7.79 \mathrm{~m}^{2} \mathrm{ha}^{-1}$ in tropical savannah of Andhra Pradesh, India; and Joseph et al., (2008) assessed $6 \mathrm{~m}^{2}$ ha $\mathrm{a}^{-1}$ for tropical scrub forest of Mudumalai, India.

However, the total BA of TTF is lower than in many dry forests of India. $21.54 \mathrm{~m}^{2} \mathrm{ha}^{-1}$ recorded for TDEF of Cuddalore, Tamil Nadu (King, 1997); $36.5 \mathrm{~m}^{2}$ ha $^{-1}$ for TDEF of Villupuram, Tamil Nadu; 27-55.3 $\mathrm{m}^{2} \mathrm{ha}^{-1}$ for the dry deciduous forest of Mandla, India (Prasad and Pandey, 1992);24.7 $\mathrm{m}^{2} \mathrm{ha}^{-1}$ for dry deciduous forests of Mudumalai, India (Sukumar et al., 1997); $46.35 \mathrm{~m}^{2}$ $\mathrm{ha}^{-1}$ for tropical dry forest of Rajasthan, India; 49.4-57.5 $\mathrm{m}^{2}$ $\mathrm{ha}^{-1}$ for deciduous forests of Andaman, India (Rasingam and Parthasarathy, 2009); and 93.53-155.48 $\mathrm{m}^{2} \mathrm{ha}^{-1}$ for tropical dry deciduous forests of Madhya Pradesh, India.

\section{Tree Population Structure Based on Basal Area}

Small diameter class had a large number of individuals, this trend changed for large diameter classes, they had a relatively small number of individuals. The study area showed a reverse J shaped population structure. This pattern indicates that the present study area supports a growing population and there are no tree felling is operative at present and as well as the recent past. Besides, a reverse J pattern of forest structure signifies healthy recruitment of trees in forest sites. Collection of fuel wood, poaching and browsing are banned in TTF, thus supporting a growing population. Forest watchers and guards regularly monitoring the forest to avoid illegal activities within the forest boundaries. In addition, people living around TTF use LPG for cooking hence their dependence on forest for fuelwood reduced dramatically.
Earlier, Udayakumar (2013), Parthasarathy and Karthikeyan (1997) and Mani and Parthasarathy (2005) reported an undisturbed tree population structure from TDEFs of the Coromandel Coast region. Similarly, Kadavul (1999) in semievergreen forests of Eastern Ghats; Rajkumar and Parthasarathy (2008) in Andaman giant evergreen forest; Sukumar et al., (1992) and Parthasarathy (2001) in Western Ghats of India reported a reverse J shaped population structure.

\section{Diversity Indices}

The Shannon index $(H)$ of TTF is higher than in tropical dry deciduous forests of Rajasthan, India (0.67-0.79; Kumar et al., 2011); tropical thorn forest of Northern India (1.39; Sharma and Chaudhry, 2018); tropical dry deciduous forests of Northwestern India (1.286-1.4; Singh and Singh, 1988); and, Kalfou reserve forest of Cameroon (1.42-1.57; Froumsia et al., 2012). Whereas, the index value of the present study is well within the range reported for five inland TDEFs of Pudukottai, Tamil Nadu (range 1.29 to 2.44; Mani and Parthasarathy, 2006); tropical dry deciduous forests of Rajasthan (1.89-2.44; Sultana et al., 2014); and, tropical dry forests of Eastern Ghats (1.1-3.5; Gopalakrishna et al., 2016). It is well known that a community is less diverse where one or few species are dominant, whereas a community is highly diverse when several species have similar abundance. The TTF is dominated by few species, for instance, Dalbergia spinosa alone constituted more than half of the tree community. Thus, the TTF secured a moderate Shannon index value $(H)$.

The Shannon equitability index (0.54) found in TTF indicates that only half of the represented species had equal opportunity. Among 26 species, ten species categorized as pre-dominant ( $>50$ individuals), six as dominant ( $>25$ to $=50$ individuals), two as common ( $>10$ to $<26$ individuals), six as rare ( $>2$ to $<11$ individuals), and four as very rare ( $<2$ individuals) in TTF.

The Simpson's dominance index of TTF $(D=0.34)$ is higher than in TDEFs of Cuddalore, Nagapattinam, Pudukottai, Tiruvarur and Villupuram (range 0.17-0.26; Parthasarathy and Karthikeyan, 1997; Venkateswaran and Parthasarathy 2003; Mani and Parthasarathy, 2005; Udayakumar, 2013). Conversely, dominance index value $(D)$ of TTF is lower than in Silent Valley, Kerala (0.06; Singh et al., 1981); Nelliampathy $(0.06 \pm 0.14$; Chandrashekara and Ramakrishnan, 1994), giant evergreen forest of Andaman (0.07, 0.12; Rajkumar and Parthasarathy, 2008). The lower the index value, the higher the community is diverse. It is well known that a community is less diverse where one or few species are dominant, whereas a community is highly diverse when several species have similar abundance. In TTF Dalbergia spinosa alone constituted one half of the tree community, thus secured a high $D$ value.

\section{Species and Family Important Values Indices}

Dalbergia spinosa, Commiphora berryi, Grewia flavescens, Dichrostachys cinerea and Anogeissus pendula are important species in TTF. Previously, Dalbergia and Anogeissus were designated as important species from tropical dry thorn forest 
(Gopalakrishnan et al., 2016). Members of the genus Anogeissus reported as one of the principal species from tropical thorn and deciduous forests of India (Sharma and Chaudhry, 2018; Yadav and Gupta, 2006; Reddy and Ugle, 2008; Kumar et al., 2011; Panda et al., 2013; Kidwai, 2013; Sultana et al., 2014; Naidu and Kumar, 2016; Tarakeswara et al., 2018).

Papilionaceae, Burseraceae, Mimosaceae, Tiliaceae and Combretaceae are the most important families in TTF. This observation is in-line with that of Tarakeswara et al., (2018), they found Combretaceae, Mimosaceae and Papilionaceae as the most important families in tropical deciduous forests of North-central Eastern Ghats, India. Panda et al., (2013) recorded Papilionaceae, Combretaceae and Mimosaceae as chief families from tropical deciduous forests of Odisha, India. Naidu and Kumar (2016) listed Combretaceae, Papilionaceae and Mimosaceae as dominant families from tropical deciduous forests of India. Froumsia et al., (2012) also encountered Combretaceae, Papilionaceae and Mimosaceae as principal families from Cameroon's Kalfou forest reserve.

\section{CONCLUSIONS}

The study area had moderate tree species richness and diversity. Besides, acts as one of the homes for an IUCN's vulnerable tree species, namely, Chloroxylon swietenia. Density, species richness and diversity of trees in TTF are comparable with similar kinds of dry forests in Tamil Nadu and other drier parts of India. A reverse J pattern of forest structure signifies healthy recruitment of trees. The collection of fuel wood, poaching and browsing are banned in TTF, thus supporting a growing population. Besides, forest watchers and guards regularly monitoring the forest to avoid illegal activities within the forest boundaries. Quantitative ecological data on TTFs have been very limited in Tamil Nadu, thus the present study hopefully paves the path to understand the ecology of less-studied forest type. Tropical thorn forest in the Uthumalai region is intact and invasive tree species are absolutely absent.

\section{ACKNOWLEDGEMENTS}

We are thankful to Science and Engineering Research Board, Ministry of Science and Technology, New Delhi for the financial support through CRG scheme (No. CRG/2019/003148 dt. $05^{\text {th }}$ February, 2020). We are grateful to the DFO, Tirunelveli for their permission to conduct field survey. Mr. S. Nagaraj, V. Muneeswaran and M. Arun Kumar helped us during field survey.

\section{REFERENCES}

Bajalwan, A. (2010). Structure, composition and diversity of degraded dry tropical forest in Balamdi watershed of Chattishgarh plain, India. Journal of Biodiversity, 1(2), 119-124.

Champion, H. G., and Seth, S. K. (1968). A revised survey of the forest types of India. Delhi, India: Manager of publications.

Chandrashekara, U. M., and Ramakrishnan, P. S. (1994). Vegetation and gap dynamics of a tropical wet evergreen forest in the Western Ghats of Kerala, India. Journal of Tropical Ecology, 10(3), 337-354. https://doi. org/10.1017/S0266467400008014

Condit, R. (1998). Tropical Forest Census Plots: Methods and Results from
Barro Colorado Island, Panama and a Comparison with Other Plots. Berlin: Springer-Verlag.

FAO, (2000). Global Ecological Zoning for the Global Forest Resources Assessment, Rome, Italy.

Froumsia, M., Zapfack, L., Mapongmetsem, P. M., and Nkongmeneck, B. A. (2012). Woody species composition, structure and diversity of vegetation of Kalfou Forest Reserve, Cameroon. Journal of Ecology and the Natural Environment, 4(13), 333-343. https://doi.org/10.5897/ JENE12.047

Gamble, J. S., and Fischer, C. E. C. (1921-35). Flora of the Presidency of Madras. 3 Vols. London: Adlard and Son Ltd.

Gillespie, T. W., Lipkin, B., Sullivan, L., Benowitz, D. R., Pau, S., and Keppel, G. (2012). The rarest and least protected forests in biodiversity hotspots. Biodiversity and Conservation, 21(14), 3597-3611. https:// doi.org/10.1007/s10531-012-0384-1

Gopalakrishna, S. P., Kaonga, M. L., Somashekar, R. K., Suresh, H. S., and Suresh, R. (2015). Tree diversity in the tropical dry forest of Bannerghatta National Park in Eastern Ghats, Southern India. European Journal of Ecology, 1(2), 12-27. https://doi.org/10.1515/ eje-2015-0013

Hansen, M. C., Potapov, P. V., Moore, R., Hancher, M., Turubanova, S. A., Tyukavina, A., Thau, D., Stehman, S. V., Goetz, S. J., Loveland, T. R., and Kommareddy, A. (2013). High-resolution global maps of 21-st century forest cover change. Science, 342(6160), 850-853. https:// doi.org/10.1126/science.1244693

Hubbell, S. P., and Foster, R. B. (1983). Diversity of canopy trees in a neotropical forest and implications for conservation. In S. J. Sutton, T. C. Whitmore and A. C. Chadwick (Eds.), Tropical Rain Forest: Ecology and Management (pp. 25-41), Oxford, UK: Blackwell Science.

Hubbell, S. P., and Foster, R. B. (1992). Short-term dynamics of a neotropical forest: why ecological research matters to tropical conservation and management. Oikos, 63(1), 48-61. https://doi. org $/ 10.2307 / 3545515$

Jha, C. S., and Singh, J. S. (1990). Composition and dynamics of dry tropical forest in relation to soil texture. Journal of Vegetation Science, 1(5), 609-614.

Joseph, S., Reddy, C. S., Pattanaik, C., and Sudhakar, S. (2008). Distribution of plant communities along climatic and topographic gradients in Mudumalai Wildlife Sanctuary (southern India). Biological Letters, 45(1), 29-41.

Kadavul, K. (1999). Biodiversity inventory and dispersion patterns of trees and lianas and stand structure in the semi-evergreen forests of Shervarayan and Kalrayan hills, Eastern Ghats, South India. Ph.D. Thesis, Pondicherry University, Puducherry, India.

Kidwai, Z. (2013). Vegetation structure and composition in core area of Sariska National Park, Rajasthan. Indian Forester, 139(7), 636-644

King, O. (1997). Botanical and socio-cultural studies on sacred groves in Cuddalore District, Tamil Nadu. M.Phil. Dissertation, University of Madras, Chennai, India.

Kowero, G. (2003). The challenge to natural forest management in SubSaharan Africa rural development: Experiences from the miombo woodlands of Southern Africa. Policies and Governance Structures in Woodlands of Southern Africa. Centre for International Forestry Research, Bogor, pp 1-8.

Krishnamurthy, Y. L., Prakasha, H. M., Nanda, A., Krishnappa, M., Dattaraja, H. S., and Suresh, H. S. (2010). Vegetation structure and floristic composition of a tropical dry deciduous forest in Bhadra wildlife sanctuary, Karnataka, India. Tropical Ecology, 51(2), 235-246.

Kumar, J. N., Patel, K., Kumar, R. N., and Kumar, R. B. (2011). Forest structure, diversity and soil properties in a dry tropical forest in Rajasthan, Western India. Annals of Forest Research, 54(1), 89-98. https://doi.org/10.15287/afr.2011.99

Magurran, A. E. (1988). Ecological diversity and its measurement. New Jersey: Princeton university press.

Mani, S., and Parthasarathy, N. (2005). Biodiversity assessment of trees in five inland tropical dry evergreen forests of peninsular India. Systematics and Biodiversity, 3(1), 1-12. https://doi.org/10.1017/ S1477200004001604

Mani, S., and Parthasarathy, N. (2006). Tree diversity and stand structure in inland and coastal tropical dry evergreen forests of peninsular India. Current Science, 90(9), 1238-1246.

Manickam, V. S., Murugan, C., Jeya-Jothi, G., and Sundaresan, V. (2008). Flora of Tirune/veli Hills (Southern Western Ghats). (Vol I), Dehradun, India: M/s. Bishen Singh and Mahendra Pal Singh. 
Mayaux, P., Holmgren, P., Achard, F., Eva, H. G., Stibig, H. J., and Branthomme, A. (2005). Tropical forest cover change in the 1990s and options for future monitoring. Philosophical Transactions of the Royal Society B: Biological Sciences, 360(1454), 373-384. https://doi. org/10.1098/rstb.2004.1590

Mclntosh, R. P. (1985). The Background of Ecology. Cambridge: Cambridge university press

Miles, L., Newton, A. C., DeFries, R. S., Ravilious, C., May, I., Blyth, S., Kapos, V., and Gordon, J. E. (2006). A global overview of the conservation status of tropical dry forests. Journal of Biogeography, 33(3), 491-505. https://doi.org/10.1111/j.1365-2699.2005.01424.x

Misra, R. (1968). Ecological work book. New Delhi, India: Oxford and IBH.

Mori, S. A., Boom, B. M., de Carbalho, A. M., and dos Santos, T. S. (1983). Southern Bahian moist forest. The Botanical Review, 49(2), 155-232. https://doi.org/10.1007/BF02861011

Murali, K. S., Shankar, U., Shanker, R. R., Ganeshaiah, K. N., and Bawa, K. S. (1996). Extraction of non-timber forest products in the forests of Bilingiri Rangan Hills, India. II. Impact of NTFP extraction on regeneration, population structure, and species composition. Economic Botany, 50(3), 252-269.

Murphy, P.G., and Lugo, A.E. (1986). Ecology of tropical dry forest. Annual Review of Ecology and Systematics, 17(1), 67-88. https://doi. org/10.1146/annurev.es.17.110186.000435

Myers, J. H., and Bazely, D. (1991). Thorns, spines, prickles, and hairs: are they stimulated by herbivory and do they deter herbivores? In D. W. Tallamy, and M. J. Raupp (Eds.), Phytochemical induction by herbivores (pp. 325-344) New York: John Wiley and Sons.

Naidu, M. T., and Kumar, O. A. (2016). Tree diversity, stand structure, and community composition of tropical forests in Eastern Ghats of Andhra Pradesh, India. Journal of Asia-Pacific Biodiversity, 9(3), 328334. https://doi.org/10.1016/j.japb.2016.03.019

Panda, P. C., Mahapatra, A. K., Acharya, P. K., and Debata, A. K. (2013). Plant diversity in tropical deciduous forests of Eastern Ghats, India: A landscape level assessment. International Journal of Biodiversity and Conservation, 5(10), 625-639. https://doi.org/10.5897/ IJBC2013.0581x

Pande, P. K. (2005). Biomass and productivity in some disturbed tropical dry deciduous teak forests of Satpura plateau, Madhya Pradesh. Tropical Ecology, 46(2), 229-239.

Parthasarathy, N. (2001). Changes in forest composition and structure in three sites of tropical evergreen forest around Sengaltheri, Western Ghats. Current Science, 80(3), 389-393.

Parthasarathy, N., and Karthikeyan, R. (1997). Plant biodiversity inventory and conservation of two tropical dry evergreen forests on the Coromandel coast, south India. Biodiversity and Conservation, 6(8), 1063-1083. https://doi.org/10.1023/A:1018328016810

Portillo-Quintero, C. A., and Sánchez-Azofeifa, G. A. (2010). Extent and conservation of tropical dry forests in the Americas. Biological Conservation, 143(1), 144-155. https://doi.org/10.1016/j. biocon.2009.09.020

Prasad, R., and Pandey, R. K. (1992). An observation on the plant diversity of Sal and Teak Forests in relation to intensity of biotic impact at various distance from habitation in Madhya Pradesh: A case study. Journal of Tropical Forest, 8(1), 62-83.

Rajkumar, M., and Parthasarathy, N. (2008). Tree diversity and structure of Andaman giant evergreen forests, India. Taiwania, 53(4), 356-368. https://doi.org/10.6165/tai.2008.53(4).356

Ramanujam, M. P., and Kadamban, D. (2001). Plant biodiversity of two tropical dry evergreen forests in the Pondicherry region of south India and the role of belief systems in their conservation. Biodiversity and Conservation, 10(7, 1203-1217. https://doi. org/10.1023/A:1016637627623

Rao, B. R. P., Babu, M. V. S., Reddy, M. S., Reddy, A. M., Rao, V. S., Sunitha, S., and Ganeshaiah. (2011). Scared groves in southern Eastern
Ghats, India: are they better managed than forest reserves. Tropical Ecology, 52(1), 79-90.

Rasingam, L., and Parthasarathy, N. (2009). Tree species diversity and population structure across major forest formations and disturbance categories in Little Andaman Island, India. Tropical Ecology, 50(1), 89-102.

Reddy, C. S., and Ugle, P. (2008). Tree species diversity and distribution patterns in tropical forest of Eastern Ghats, India: a case study. Life Science Journal, 5(4), 87-93.

Sagar, R., Raghubansi, A.S., and Singh, J.S. 2003. Tree species composition, dispersion and diversity along a disturbance gradient in a tropical dry forest region of India. Forest Ecology and Management, 186(1-3), 61-71. https://doi.org/10.1016/S0378-1127(03)00235-4

Shankar, U., Murali, K. S., Uma-Shaanker, R., Ganeshaiah, K. N., and Bawa, K. S. (1998). Extraction of Non-Timber Forest Products in the Forests of Biligiri Rangan Hills, India.4. Impact on floristic diversity and population structure in a thorn scrub forest. Economic Botany, 52(3), 280-293. https://doi.org/10.1007/BF02862149

Sharma, V., and Chaudhry, S. (2018). Vegetation composition and plant diversity in mining disturbed tropical thorn forest of Asola-Bhatti Wildlife Sanctuary, Northern India. Taiwania, 63(3), 267-280. https:// doi.org/10.6165/tai.2018.63.267

Shepherd, G., Chipeta, M., and Campbell, B. (2002). Africa's Tropical Dry Forests - Time to re-engage: An agenda for priority research. Centre for International Forestry Research, Bogor.

Singh, J. S., Singh, S. P., Saxena, A. K., and Rawat, Y. S. (1981). The Silent valley forest ecosystem and possible impact of proposed hydroelectric project. Reports on the Silent valley study. Ecology Research Circle, Kumaun University, Nainital, India.

Singh, K. P., and Singh, J. S. (1988). Certain structural and functional aspects of dry tropical forests and savanna. International Journal of Ecology Environmental Science, 14(1), 31-45.

Sukumar, R., Dattaraja, H. S., Suresh, H. S., Radhakrishnan, J., Vasudev, R., Nirmala, S., and Joshi, N. V. (1992). Long-term monitoring of vegetation in a tropical deciduous forest in Mudumalai, Southern India. Current Science, 62(9), 608-616.

Sukumar, R., Suresh, H. S., Dattaraja, H. S., and Joshi, N. V. (1997). The spatial organization of plant communities in a deciduous forest: A comparative geometry based analysis. Journal of the Indian Institute of Science, 77(4), 365-374.

Sultana, A., Hussain, M. S., and Rathore, D. K. (2014). Diversity of tree vegetation of Rajasthan, India. Tropical Ecology, 55(3), 403-410.

Tarakeswara-Naidu, M., Premavani, D., Suthari, S., and Venkaiah, M. (2018). Assessment of tree diversity in tropical deciduous forests of Northcentral Eastern Ghats, India. Geology, Ecology, and Landscapes, 2(3), 216-227. https://doi.org/10.1080/24749508.2018.1452479

Tiwari, U. L., and Ravikumar, K. (2018). Floristic Diversity and Vegetation Analysis of Plants from Various Forest Types in Hosur Forest Division, Tamil Nadu, Southern India. Notulae Scientia Biologicae, 10(4), $597-$ 606. https://doi.org/10.15835/nsb10410382

Udayakumar, M. (2013). Ecological Studies on Selected Tropical Dry Evergreen Forests of Southern Coromandel Coast, Peninsular India. Ph.D. Dissertation, University of Madras, Chennai, India.

Utkarsh, G., Joshi, N. V., and Gadgil, M. (1998). On the patterns of tree diversity in the Western Ghats of India. Current Science, 75(6), 594-603.

Venkateswaran, R., and Parthasarathy, N. (2003). Tropical dry evergreen forests on the Coromandel coast of India: Structure, composition and human disturbance. Ecotropica, 9(1-2), 45-58.

Yadav, A. S., and Gupta, S. K. (2006). Effect of micro-environment and human disturbance on the diversity of woody species in the Sariska Tiger Project in India. Forest Ecology and Management, 225(1-3), 178-189. https://doi.org/10.1016/j.foreco.2005.12.058 